\title{
Estimation of Runoff by using SCS Curve Number Method Integrated with GIS
}

\author{
P ANIL KUMAR ${ }^{1}$, Dr GK VISWANADH ${ }^{2}$ \\ Head of The Department, Civil Engineering, KN Polytechnic Hyderabad, Telangana, India ${ }^{1}$ \\ Professor in Civil Engineering and OSD To VC, JNTUH, Hyderabad, Telangana, India ${ }^{2}$
}

\begin{abstract}
Rainfall, runoffs are the most important hydrological variables used in the most of the water resources applications. The information pertaining to occurrence of runoff further helps in water management practices. Runoff is normally generated on limited areas i.e. impervious or less impervious areas, saturated areas etc. Whereas neighboring vegetated areas do not generate any direct runoff. This needs to be taken into account of rainfall-runoff modeling and thus in the delineation of the areas. The input parameters which influence runoff component vary spatially at micro levels. A runoff model has been developed on the basis of SCS-CN method in the present study for predicting runoff.
\end{abstract}

Keywords: Rainfall, Runoff, SCS-CN, Remote Sensing And GIS.

\section{INTRODUCTION}

The precipitated rainfall percolates in to the ground as ground water and reaches to the ocean as surface runoff and sub surface runoff through streams. The direct surface runoff/ storm runoff is the part which joins the stream after rainfall. Topographic features, the degree of development, the gradient of channels, and the extent and slope of the ground affect the rates and volumes of runoff. Slope with extensive flat areas or depressed areas without surface outlets have lower runoff than the areas with steep slope and well defined drainage patterns. The geologic or soil material contribute to a large degree of the infiltration rate, and thus affect runoff vegetation and the practices incident to agriculture and forestry (Schwab et al., 2002). The several factors which affects runoff usually vary considerably on a drainage basin during different storms. A direct plotting of rainfall against runoff for individual storms does not produce a satisfactory correlation. The rainfall-runoff relation may be greatly enhanced by taking into account as parameters, some influencing factors such as storm frequency, condition of initial soil moisture, duration of storm and the year (Langbein, 1949). Runoff is one of the important hydrologic variables used in most of the water resource applications. The central water commission (CWO, 1988) has estimated, on basis of the statistical analysis of available data, the total average annual runoff of the river systems of India as $1,881 \mathrm{~km} 3$. About $80 \%$ of this flow occurs during monsoon months. The medium and minor catchments of India have 7\% and 8\% of annual runoff respectively (Rao, 1975). Planning and water resources development projects require the stream flow data where as hydrological models for prediction of stream discharge require meteorological data and also spatially distributed data like topography, hydrology, soil physics and land use. GIS and RS technology can enhance conventional methods extremely in the study of rainfall-runoff. The task of RS in calculating runoff generally provides input data source or to assist the estimation of equation coefficients or generating thematic layers such as land use, soil, drainage etc.

In the absence of direct measurement of runoff, rainfall-runoff relationships developed for a hydrologically homogeneous region can be used for the estimation of yields. The most commonly used method for rain storm occurrence in unguaged basins depends on runoff curve numbers developed by USDA, Soil Conservation Service (SCS, 1985). The SCS curve number technique is a widely accepted tool in hydrology. This is a simple conceptual method. It relies on one constraint and on four important catchment properties such as type of soil, surface, land use and antecedent moisture conditions increased its popularity. Chatterjee et al. (1997) and Shrivastava and Bhatia (1992) have used SCS curve number method for estimating runoff from small watersheds and found that the predicted runoff hydrograph are in good agreement with the observed runoff hydrographs. The, SCS method has been modified in the last few years by many researchers to estimate runoff more accurately and to have flexibility in using this model for other conditions also. Mishra and Singh (1999) modified the SCS curve number technique for Indian conditions using the data of five watersheds. They critically explained and generalized the relation between potential maximum retention and curve number. In general, this model suits for small watersheds with less than 4,000 ha. Though, with increase in the availability of finer spatial resolution information from space based RS data on vegetation, it is possible to use the SCS model for larger areas by means of enhanced accuracy (Kumar et al., 1997). 
UGC Approved Journal

IARJSET

\section{STUDY AREA}

The study area Hyderabad is situated between $17 \square 20^{\prime} \& 17025^{\prime}$ of the northern latitude and $78 \square 25^{\prime} \& 78035^{\prime}$ of eastern longitude, 520mts above M.S.L covers in SOI toposheet nos 56k/6, 56k/7, 56k/10 and 56k/11. The Hyderabad city is located on Krishna basin. Musi River, the tributary of river Krishna, which passes through the city of Hyderabad and divides the city as north \& south Hyderabad. The Hyderabad occupies an area of $217 \mathrm{sq} \mathrm{km}$ with density population of 14,497 per sq $\mathrm{km}$. As per 2011 census The total population of district is $6,809,970$.

\section{Materials AND Methodology}

Survey of India Toposheets Nos. 56k/6, 56k/7, 56k/10 and 56k/11 scale 1:25,000 published in 1971 were used. The daily rainfall data is collected from the period of 1971 to 2011 from Bureau of Statistics And Economics,Hyderabad.

\section{SCS RUNOFf CURVE NuMber METHOD}

This technique is considered reliable and computationally efficient. Determination of curve number rely on watershed's soil \& cover conditions that represents HSG, cover type, treatment and hydrologic condition. Basing on this method the idea of proportionality in comparison with retention and runoff is defined as.

$$
\frac{(\mathrm{P}-\mathrm{Q})}{\mathrm{S}}=\frac{\mathrm{Q}}{\mathrm{P}} \quad \ldots \ldots \ldots \ldots \ldots \ldots \ldots
$$

The ratio of actual retention to potential retention of rainfall is equal to the ratio of actual runoff to rainfall minus initial abstraction. This assumption emphasizes conceptual basis of runoff curve number technique. P, Q and S are stated in same units i.e. $\mathrm{mm}$ or inches.

Mathematically it can be expressed as,

$$
\frac{\mathrm{P}-\mathrm{I}_{\mathrm{a}}}{\mathrm{S}}-\mathrm{Q}
$$

This can be rearranged as

$$
\mathrm{Q}=\frac{\left(\mathrm{P}-\mathrm{I}_{\mathrm{a}}\right)^{2}}{\left(\mathrm{P}-\mathrm{I}_{\mathrm{a}}\right)+\mathrm{S}} \quad \ldots \ldots \ldots \ldots \ldots \ldots \ldots \ldots
$$

The losses before runoff begin. It comprises water saved in surface depressions and water intercepted through vegetation, evaporation and infiltration. Hence Ia is extremely changeable and is correlated by soil and cover parameters. Subsequent to several studies Ia is estimated through following empirical equation.

$$
\mathrm{Ia}=0.2 \mathrm{~S}
$$

Substituting Ia in 2

We get

$$
\mathrm{Q}=\frac{(\mathrm{P}-0.2 \mathrm{~S})^{2}}{(\mathrm{P}+0.8 \mathrm{~S})}
$$

Where

$\mathrm{Q}=$ direct runoff in $\mathrm{mm}($ actual $)$

$\mathrm{P}=$ storm rainfall in $\mathrm{mm}($ total $)$

$\mathrm{S}=$ maximum potential retention of water by the soil in $\mathrm{mm}$

The retention parameter (S) differs spatially, due to change in soil, LU, slope and temporally due to change in content of soil water. In the evaluation of antecedent rainfall, soil conditions, LU and conservation practices (SCS, 1985) define: 
UGC Approved Journal

$$
\mathrm{S}=25.4\left(\frac{1000}{\mathrm{CN}}-10\right)
$$

Where

$\mathrm{CN}$ is an arbitrary curve number varying from 0 to 100

According to Indian conditions the relation between max potential retention and initial abstraction is developed (Dhruva Narayana, 2002).

(a) For black soil regions (AMC-I) and for all other regions: Initial abstraction, $\mathrm{Ia}=0.3 \mathrm{~S}$

(b) For black soil region (AMC- II and III): Initial abstraction, Ia $=0.1 \mathrm{~S}$

The present study is applicable to all the soil regions except black soil regions in India the following equation is used for the estimation of runoff.

$$
Q=\frac{(P-0.3 S)^{2}}{(P+0.7 S)} \quad \ldots \ldots \ldots \ldots . .5
$$

\section{RESUlTS AND DisCUSSIONS}

Daily rainfall data have been collected from the period 1971 to 2011 from Bureau of Statistics and Economics, Hyderabad.

Trend analysis of yearly rainfall is shown in fig 1 .

Similarly, runoff data has been carried out and presented and processed to monthly and yearly runoff for the further analysis.

Fig 2 shows the trend analysis of runoff for the study area. Variations of yearly rainfall and calculated runoff for the years 1971 to 2011 is shown in fig 3.

Various year wise observations for the trend line equation for the runoff and coefficient of determination or goodness of fit is represented in the table I

The trend line equation for runoff in the year 1971 is shown as $y=4.376 x+1.7724$. Where $x$-axis represents year and $y-$ axis represents yearly runoff in $\mathrm{mm}$ in that year. The trend lines of both yearly rainfall and yearly runoff show variations in the study area.

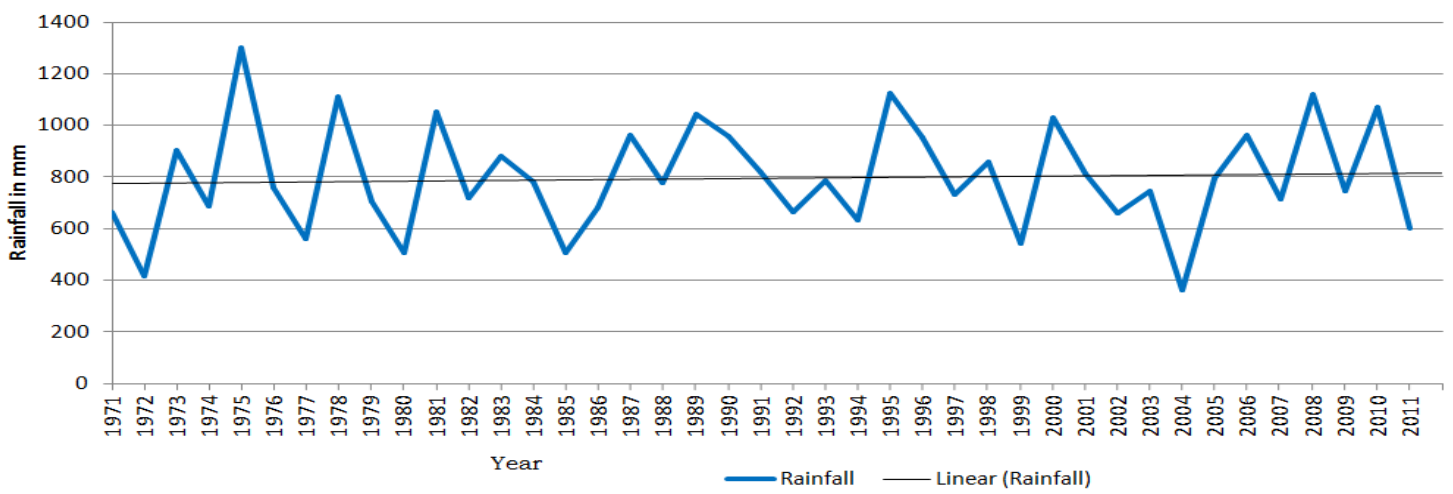

Fig 1. Trend Analysis of Rainfall for the study area

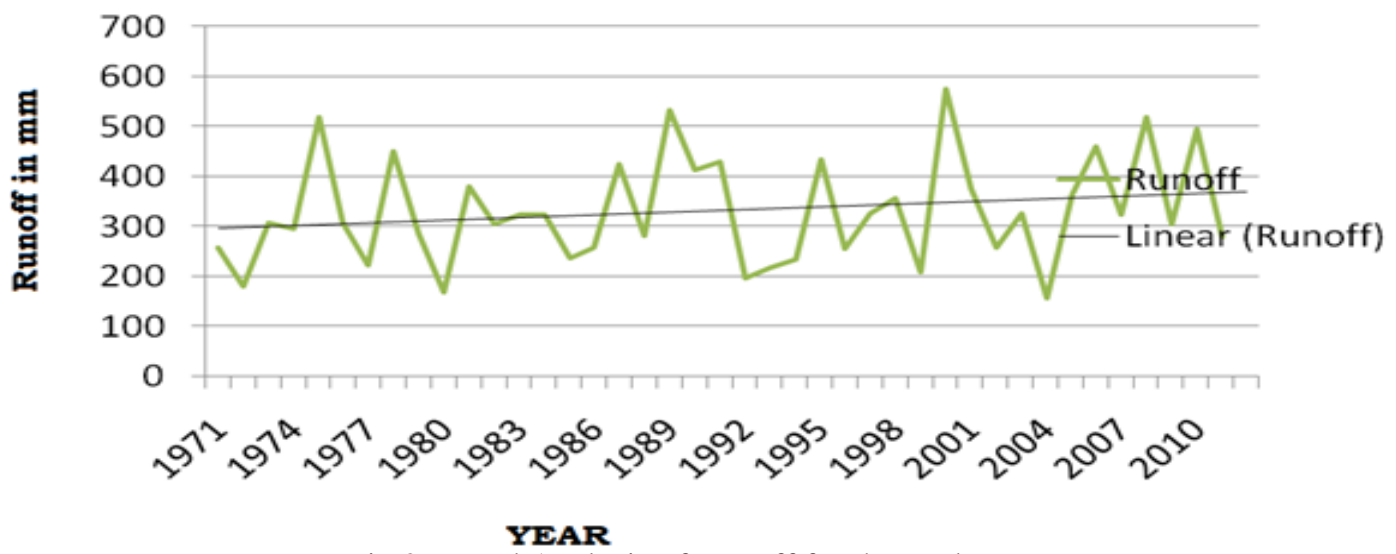

Fig 2. Trend Analysis of Runoff for the study area 
UGC Approved Journal

IARJSET

International Advanced Research Journal in Science, Engineering and Technology ISO 3297:2007 Certified

Vol. 4, Issue 7, July 2017

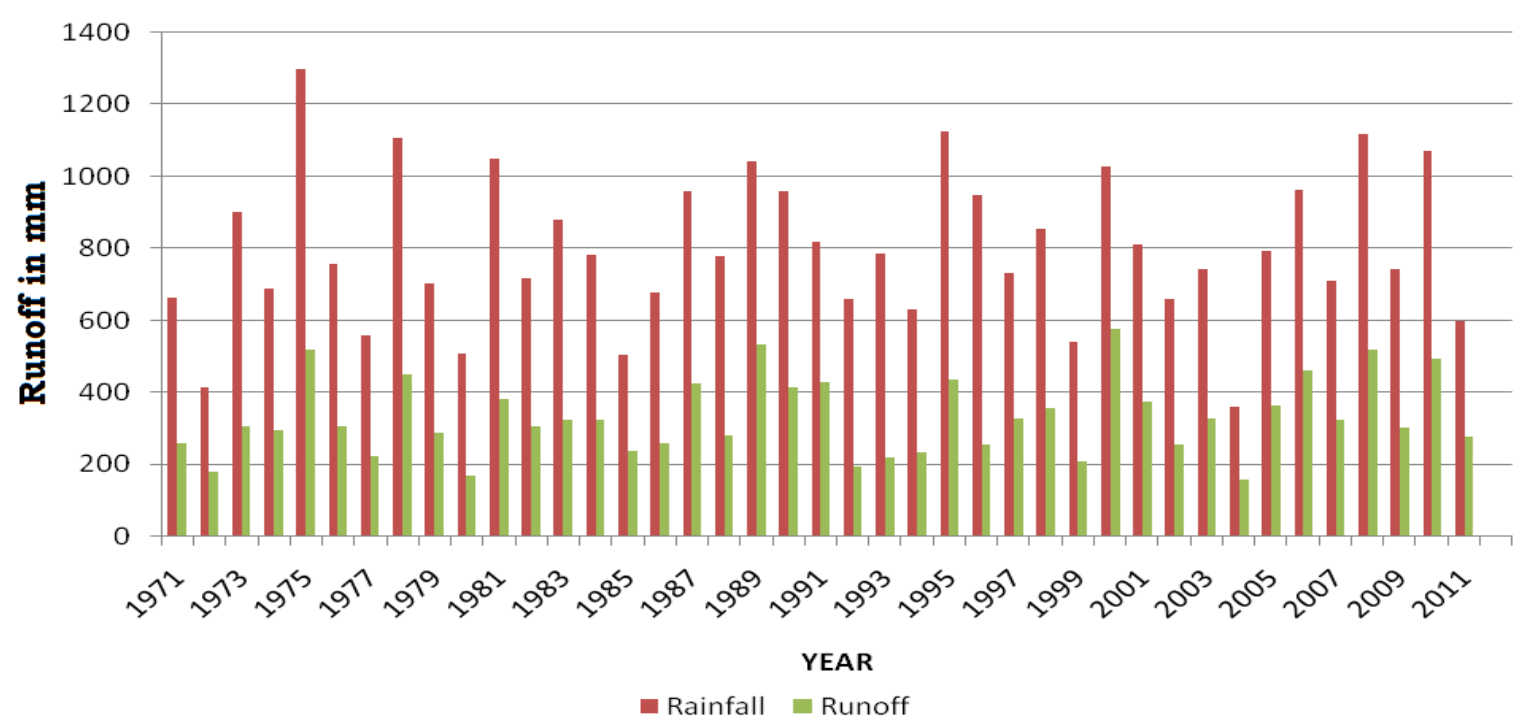

Fig 3. Variation of Yearly Rainfall and calculated yearly runoff for from 1971 to 2011

\section{Table I}

Trend line equations for Runoff and Coefficient of determination from the year 1971 to 2011

\begin{tabular}{|c|c|c|c|}
\hline S.No & Year & Trend line equation for Runoff & $\begin{array}{l}\mathbf{R}^{2}=\text { Coefficient of determination or } \\
\text { goodness of fit }\end{array}$ \\
\hline 1 & 1971 & $\mathrm{y}=4.376 \mathrm{x}+1.7724$ & 0.8965 \\
\hline 2 & 1972 & $y=0.3878 x+1.6086$ & 0.9314 \\
\hline 3 & 1973 & $y=0.3563 x+1.1943$ & 0.9256 \\
\hline 4 & 1974 & $y=0.4138 x+1.0069$ & 0.9778 \\
\hline 5 & 1975 & $y=0.3983 x+0.0821$ & 0.9687 \\
\hline 6 & 1976 & $y=0.4101 x-0.2604$ & 0.9966 \\
\hline 7 & 1977 & $y=0.343 x+2.6103$ & 0.8495 \\
\hline 8 & 1978 & $y=0.4429 x-3.3349$ & 0.9906 \\
\hline 9 & 1979 & $y=4.135 x+0.2675$ & 0.9567 \\
\hline 10 & 1980 & $y=0.3344 x+0.0245$ & 0.9451 \\
\hline 11 & 1981 & $y=0.3878 x-2.2368$ & 0.9307 \\
\hline 12 & 1982 & $y=0.4028 x+1.3924$ & 0.937 \\
\hline 13 & 1983 & $y=0.3541 x+1.0821$ & 0.9664 \\
\hline 14 & 1984 & $y=0.4033 x+0.835$ & 0.9472 \\
\hline 15 & 1985 & $y=0.4206 x+2.0695$ & 0.9661 \\
\hline 16 & 1986 & $y=0.3899 x-0.5173$ & 0.9855 \\
\hline 17 & 1987 & $y=0.4178 x+1.947$ & 0.9029 \\
\hline 18 & 1988 & $y=0.3766 x-0.9756$ & 0.99 \\
\hline 19 & 1989 & $y=0.5464 x-2.9191$ & 0.9876 \\
\hline 20 & 1990 & $y=0.3784 x+4.276$ & 0.9072 \\
\hline 21 & 1991 & $y=0.5522 x-1.7786$ & 0.9921 \\
\hline 22 & 1992 & $y=0.3041 x-0.4518$ & 0.8222 \\
\hline 23 & 1993 & $y=0.2287 x+3.2128$ & 0.8228 \\
\hline 24 & 1994 & $y=0.4011 x-1.5624$ & 0.9005 \\
\hline
\end{tabular}


UGC Approved Journal

IARJSET

ISO 3297:2007 Certified

Vol. 4, Issue 7, July 2017

\begin{tabular}{|l|l|l|l|}
25 & 1995 & $\mathrm{y}=0.3834 \mathrm{x}+0.2919$ & 0.9905 \\
\hline 26 & 1996 & $\mathrm{y}=0.313 \mathrm{x}-3.5518$ & 0.9207 \\
\hline 27 & 1997 & $\mathrm{y}=0.4718 \mathrm{x}-1.5161$ & 0.9204 \\
\hline 28 & 1998 & $\mathrm{y}=0.4099 \mathrm{x}+0.5585$ & 0.9465 \\
\hline 29 & 1999 & $\mathrm{y}=0.3889 \mathrm{x}-0.3571$ & 0.9581 \\
\hline 30 & 2000 & $\mathrm{y}=0.5915 \mathrm{x}+2.7234$ & 0.9777 \\
\hline 31 & 2001 & $\mathrm{y}=0.4613 \mathrm{x}+0.1582$ & 0.9305 \\
\hline 32 & 2002 & $\mathrm{y}=0.4291 \mathrm{x}-2.1417$ & 0.9677 \\
\hline 33 & 2003 & $\mathrm{y}=0.4313 \mathrm{x}+0.544$ & 0.9839 \\
\hline 34 & 2004 & $\mathrm{y}=0.4426 \mathrm{x}-0.2785$ & 0.9968 \\
\hline 35 & 2005 & $\mathrm{y}=0.4396 \mathrm{x}+1.1734$ & 0.9947 \\
\hline 36 & 2006 & $\mathrm{y}=0.4788 \mathrm{x}+0.1012$ & 0.9978 \\
\hline 37 & 2007 & $\mathrm{y}=0.4754 \mathrm{x}-1.1821$ & 0.9924 \\
\hline 38 & 2008 & $\mathrm{y}=0.4611 \mathrm{x}+0.1882$ & 0.9992 \\
\hline 39 & 2009 & $\mathrm{y}=0.3708 \mathrm{x}+2.3933$ & 0.9883 \\
\hline 40 & 2010 & $\mathrm{y}=0.4574 \mathrm{x}+0.4923$ & 0.9966 \\
\hline 41 & 2011 & $\mathrm{y}=0.4885 \mathrm{x}+1.2256$ & 0.9963 \\
\hline
\end{tabular}

\section{VI.CONCLUSIONS}

The precise conclusions of the study area are mentioned below:

1. Representation of rainfall analysis indicating increasing trend is given by equation. $\mathrm{y}=0.9675 \mathrm{x}+776.53$

2. Representation of yearly runoff indicating increasing trend line is given by equation. $\mathrm{y}=1.7785 \mathrm{x}+294.18$

3. Yearly rainfall and yearly runoff shows increasing trend.

4. The present study demonstrated the use of GIS and RS in assisting the development of a model to predict runoff.

5. This study would help to promote a wide range of options to promote/interventions to formulate the decisions aimed at improving ground water management.

\section{REFERENCES}

[1] Ajaykumar K.Kadam et al, Identifying Potential Rainwater Harvesting Sites of a Semi-arid, Basaltic Region of Western India, Using SCS-CN Method, 2012.

[2] Amarinder Singh, Characterising Runoff Generation Mechanism for Modelling Runoff and Soil Erosion, In Small Watershed of Himalayan Region, 2009.

[3] Andy D Ward, William J Elliot, Environmental Hydrology, Lewis Publishers, 1995.

[4] Anjaneyulu Y., (Editor Prof.P.Narasimha Rao), "Introduction to Environmental Science", BS Publications, Hyderabad, (First reprint 2005)

[5] Reddy M., Text Book of Anji RS and GIS, Second edition, B.S Publications, Hyderabad, 2001.

[6] C Chatterjee, R Jha, A K Lohani and R K Jaiswal. .Determination of SCS Curve Number and Landuse Changes for Hamidnagar Sub-basin of Punpun Basin, National Institute of Hydrology, Roorkee, 1997 CS(AR) 14/96-97.

[7] Cheng Q, Ko C, Yuan Y, Ge Y, Zhang S GIS modeling for predicting river runoff volume in ungauged drainages in the Greater Toronto Area, Canada. Comput Geosci, 2006, 32(8):1108-1119.

[8] chwab G O, Frevert R K (1993) Elementary soil and water engineering.

[9] D. Ramakrishnan, A. Bandyopadhyay, K. N. Kusuma, SCS-CN and GIS-based approach for identifying potential water harvesting sites in the Kali Watershed, Mahi River Basin, India, Journal of Earth System Science, August 2009, Volume 118, Issue 4, pp 355-368.

[10] D.J. Maguire, M.F. Goodchild, and D.W. Rhind (eds), Geographical Information Systems, I: Principles. Longman Scientific and Technical, Harlow, 1991, pp. 239-49.

[11] Mishra S. K. and Singh V. P., Another look at SCS-CN method, Journal of Hydrological Engineerin, 1999, ASCE 4: $257-264$. Thomas M Lillesand and Ralph W keifer, Remote Sensing and Image Interpretation, John Wiley and sons, New York, 2000. 